Platskamp, specialnummer av

Arkiv. Tidskrift för sambällsanalys, nr 9 (2018)

\title{
Förändringens agenter. Om skola, prevention och fostran till trygghet
}

\section{Magnus Dahlstedt \& Christophe Foultier}

SAmmandrag: Magnus Dahlstedt och Christophe Foultiers artikel undersöker trygghetsskapande åtgärder inriktade mot skolan. Syftet är att undersöka en specifik intervention för brottsförebyggande fostran som har sjösatts i ett förortsområde, med avseende på hur denna fostran iscensätts (dvs. genom vilka tekniker), vilka motiv som finns till den (dvs. vilka utmaningar den svarar mot) och - slutligen - vad det är för slags subjekt som denna fostran är tänkt att resultera i (dvs. vilka förmågor och egenskaper detta tänkta subjekt har). Analysen tar avstamp i en teoretisk ansats influerad av Michel Foucault och hans tankar om makt och styrning och specifikt hur de har tillämpats på frågor om skola, lärande och utbildning. Analysen pekar på en fostran som bygger på ett slags vilja att aktivera, en form av styrning som frammanar individens motivation och vilja att göra aktiva val och aktiva ställningstaganden - i namn av frihet, ansvarstagande och trygghet.

NYCKELORD: fostran; styrning; governmentality; brottsprevention; trygghet; ungdomar; förorten.

PUBLICERINGSHISTORIK: Originalpublicering.

MAGNUS DAHLSTEDT är professor i socialt arbete vid Linköpings universitet.

E-POSTADRESS: magnus.dahlstedt@liu.se

CHRISOPHE FOULTIER är postdoktor vid REMESO vid Linköpings universitet.

E-POSTADRESs: christophe.foultier@liu.se

FÖRSLAG PÅ KÄLLANGIVELSE:

Dahlstedt, Magnus \& Christophe Foultier (20I8) ”Förändringens agenter. Om skola, prevention och fostran till trygghet", i Platskamp, specialnummer av Arkiv. Tidskrift för sambällsanalys, nr 9, s. I59-I8I.

DOI: https://doi.org/10.13068/2000-6217.9.6

(C) Författarna/Arkiv förlag \& tidskrift 2018 (publicerad 28 maj 20ı8)

Artikeln distribueras enligt en upphovsrättslicens från Creative Commons:

Erkännande-Ickekommersiell-IngaBearbetningar 3.0 Unported, som medger fri ickekommersiell användning och spridning i oförändrat skick så länge källan anges. 
Arkiv. Tidskrift för samhällsanalys är en sakkunniggranskad vetenskaplig tidskrift för samhällsvetenskap och historia. Samtliga artiklar publiceras fritt tillgängliga på:

$$
\text { www.tidskriftenarkiv.se }
$$

Beständig länk, DOI: https://doi.org/IO.I3068/2000-62I7

Den här artikeln finns tillgänglig i följande format:

PDF: via beständig länk, DoI: https://doi.org/IO.I3068/2000-6217.9.6

TRYCK: ingår i bokutgåva av numret, ISBN: 978 9I 79243159

Grafisk utformning och sidnumrering är identisk i pdf och tryck.

Samtliga artiklar i nr 9 (2018), Platskamp, nås via beständig länk, DOI: https://doi.org/I0.I3068/2000-6217.9

Redaktion för nUmret: Magnus Dahlstedt, Lisa Kings \& Nazem Tahvilzadeh

Arkiv. Tidskrift för sambällsanalys

ISSN: 2000-62I7 (för elektronisk resurs)

ISSN: 2000-6225 (för tryckta nummer)

ges ut av

Stiftelsen Arkiv för främjande och spridning av samhällsvetenskaplig och historisk forskning

genom

Arkiv förlag \& tidskrift

Box 1559

SE-22I OI Lund

BESÖK: L Gråbrödersg 3 c, ipg

TEL: 046-I3 3920

ARKIV FÖRLAG: arkiv@arkiv.nu·www.arkiv.nu

TIDSKRIFTEN ARKIV: red@tidskriftenarkiv.se.www.tidskriftenarkiv.se

ANSVARIg UTGIVARE \& CHEFREDAKTÖR: Sven Hort

AdMinistrativ Redaktör: David Lindberg

Redaktörer: Paavo Bergman, Per Dannefjord, Lisa Kings,

Zhanna Kravchenko, Anna-Maria Sarstrand Marekovic 


\section{Förändringens agenter. Om skola, prevention och fostran till trygghet}

\section{MAGNUS DAHLSTEDT \& CHRISTOPHE FOULTIER}

\section{Inledning}

Under de senaste åren har stor uppmärksamhet ägnats åt frågan om en påstått växande otrygghet och en ökande ungdomsbrottslighet. Som ett svar på detta uppmärksammade trygghetsproblem har en bred repertoar av åtgärder tagits fram och satts i bruk runt om i Sverige, inte minst i relation till städernas förortsområden (Listerborn 2002; Mulinari 2015). Många av dessa åtgärder bygger på samverkan mellan lokala aktörer, däribland polis, räddningstjänst, socialtjänst - och skola. I fokus för följande artikel står just trygghetsskapande åtgärder som inriktar sig på skolan - ordnade i samverkan mellan lokala aktörer. Vi ägnar oss närmare bestämt åt att undersöka den form av brottsförebyggande fostran som under de senaste åren kommit att få en alltmer framträdande roll i det breda trygghetsskapande arbete som bedrivs runt om i landet (Popkewitz m.fl. 2006; Wahlgren 20I4).

Artikeln tar sin utgångspunkt i ett forskningsprojekt om samverkan som medel i det brottsförebyggande arbetet i fyra förortsområden i två svenska städer (se vidare Dahlstedt \& Lozic 20I7). Syftet med artikeln är att analysera en specifik intervention för brottsförebyggande fostran som har sjösatts i ett av dessa områden, med avseende på hur denna fostran iscensätts (det vill säga genom vilka tekniker), vilka motiv som finns till denna fostran (det vill säga vilka utmaningar den svarar mot) och 
- slutligen - vad det är för slags subjekt som denna fostran är tänkt att resultera i (det vill säga vilka förmågor och egenskaper detta tänkta subjekt har). Analysen tar avstamp i en teoretisk ansats influerad av Michel Foucault och hans tankar om makt och styrning och specifikt hur de har tillämpats på frågor om skola, lärande och utbildning.

Artikeln är upplagd enligt följande: Först sätts frågan om brottsförebyggande fostran in i ett bredare sammanhang. Därpå presenteras den teoretiska ansats som väglett analysarbetet. Därefter presenteras de huvudsakliga resultaten av vår analys - inledningsvis med fokus på hur det brottsförebyggande arbetet beskrivs generellt, i de undersökta områdena, och därefter med fokus på den specifika intervention i ett av de områden som undersökts (motiv, tekniker och tänkta effekter). Avslutningsvis diskuteras studiens huvudsakliga slutsatser utifrån de utmaningar och omvandlingar som det brottsförebyggande arbetet står inför - en bit in på det nya millenniet.

\section{Brottsförebyggande fostran - kontinuitet och förändring}

Skolan som en arena för trygghetsskapande åtgärder i samhället är ingen ny företeelse. Frågan om skolans betydelse i det brottsförebyggande arbetet har i olika tappning återkommit under hela efterkrigstiden. Under 1950- och 1960-talen sågs skolan som en viktig del i det brottsförebyggande arbetet, främst utifrån dess potential att "observera, upptäcka och åtgärda de elever som kunde ligga i riskzonen för att utveckla kriminalitet” (Wahlgren 20I4, s. 95). Först på 1970-talet började skolans potential i arbetet med normer och värderingar lyftas fram i det brottsförebyggande arbetet. Idén om skolan som en arena för brottsförebyggande fostran fick nu stort genomslag. Skolans fostransuppdrag definierades nu som del av ett långsiktigt samhällsbygge där unga skulle förmås att bli demokratiska medborgare. Ambitionen var att skolans fostran skulle bidra till strukturella förändringar i samhället.

Synen på det brottsförebyggande arbetet och skolans roll i detta sammanhang kom dock att förändras (Hörnqvist 20IO; Wahlgren 20I4). Dessa förändringar kan i sin tur ses i ljuset av en bredare omvandling 
av den svenska välfärdsstaten (Andersson \& Nilsson 2009; Dahlstedt 2009a). I stället för att fokusera på strukturella förändringar kom det brottsförebyggande arbetet alltmer att fokusera på övervakning och kontroll (Sahlin 200o). Med denna förskjutning träder individen och individens ansvar fram i förgrunden, och liksom i andra sammanhang framstår individen som både problem och lösning. In på det nya millenniet tar skolans brottsförebyggande fostran form som "en aktiverande pedagogik med fokus på att göra elever delaktiga" - härmed "framträder eleven som ett ansvarstagande subjekt" (Wahlgren 20I4, s. 202). Fostran av elever till ansvarstagande subjekt är, till skillnad från tidigare, inte del av en bredare strävan efter att åstadkomma långsiktiga strukturella förändringar, utan den är snarare del av en mer kortsiktig strävan efter att identifiera och hantera risker i vardagen, runt om i samhället (Andersson \& Nilsson 2009; O’Malley 20I2). Denna fostran går därmed ut på att "lära eleverna att tänka i trygghetstermer, exempelvis hur de kan förebygga och åtgärda otrygghet", samt "lära sig att upptäcka vad som ... gör dem otrygga" (Wahlgren 20I4, s. 203). Alla tänkbara aktörer i lokalsamhället mobiliseras i arbetet med att identifiera och hantera potentiella risker (Petersson 1997). Brottsförebyggandet sprids följaktligen ut och kommer att omfatta hela samhällskroppen (O’Malley 2012).

Skiftet i synen på det brottsförebyggande arbetet och skolans roll hänger i sin tur samman med en framväxande problembild enligt vilken ungdomar kommit att ses som ett växande samhällsproblem. Inte minst har fokus riktats mot en generellt ökad psykisk ohälsa, i synnerhet bland så kallade riskungdomar (youth at risk; se Riele 2006; Wishart m.fl. 2006). I detta sammanhang har stor uppmärksamhet riktats mot betydelsen av att individen arbetar med sig själv, för att bli mer medveten om sina begränsningar och förmågor, för att förbättra sitt självförtroende och lära sig hantera sina känslor. Strävan efter trygghet är ett viktigt ändamål med detta arbete.

Frank Furedi (2004) har beskrivit detta fokus på arbete med självet i termer av en "terapeutisk kultur", grundad i en psykologisk förståelse av individ och samhälle (jfr Johansson 2006). En terapeutisk modell som haft stort genomslag är KBT, kognitiv beteendeterapi. KBT går ut på att förändra oss själva, våra själv, hur vi tänker om våra attityder, mål 
och önskningar (Andersson 2004). Modellen inbegriper en terapeut som använder en rad metoder för att få patienterna att vilja arbeta med sig själva och sina inre liv, som ett medel för att utveckla sin "sociala kompetens" och sitt "moraliska resonerande" (se Andersson 2008; Hörnqvist 20IO). Nyckeln till framgång, enligt KBT-konceptet, är att fokusera på möjligheter och inte på svårigheter och problem - ett fokus på de senare löser nämligen inte några problem utan låser snarare fast individens tänkande i negativa mönster.

Sedan 1990-talet har olika slags terapeutiska modeller, inte sällan inspirerade av KBT, fått allt större spridning inom verksamhetsområden som psykiatri, kriminalvård, socialt arbete (se t.ex. Petersson 2003; Andersson 2008) och inte minst inom skolans värld - i Sverige (Skolverket 20II; Irisdotter Aldenmyr 20I4; Fejes \& Dahlstedt 20I2), liksom i en rad andra länder (Feindler \& Weisner 2006; Gundersen \& Svartdal 2006). En rad forskare har undersökt tillämpandet av sådana terapeutiska modeller i svensk skola (Bartholdsson 2007; Löf 20II; Axelsson \& Qvarsebo 20I4; Irisdotter Aldenmyr 20I4; Kvist Lindholm 2015). På bred front initieras alltså arbetssätt som på olika sätt riktar sig mot skolan med syfte att frammana särskilda normer och värderingar för att på så sätt skapa trygghet -i skolan och i det omgivande samhället. I följande artikel riktas fokus mot hur det trygghetsskapande arbetet i skolan kan gestaltas, med utgångspunkt i en undersökning av brottsförebyggande arbete i fyra områden runt om i Sverige. Innan vi går närmare in på själva analysen ska vi dock presentera den analytiska ansats som vägleder vår analys samt det empiriska material som analyseras.

\section{Analytiskt perspektiv}

Utgångspunkten för denna artikel är begreppet "governmentality", ett begrepp som utvecklats med utgångspunkt i Michel Foucaults teorier om maktens natur i det moderna samhället (Cruikshank 1999; Dean I999; Rose 1999). I varje samhälle, vid varje tid, etableras enligt Foucault (I980) bestämda "sanningsregimer" (regimes of truth), som anger ramarna för vad det till exempel innebär att vara medborgare, vilka egenskaper, förmågor och karaktärsdrag en god medborgare bör ha. 
Begreppet governmentality beskriver en mer komplex form av styrning än den som vanligtvis avses med termen "government" (Rose 1999). Begreppet har översatts till svenska på flera olika sätt, varav ett av de mer välgrundade är "styrningskonst" (se Kihlberg 2006, s. 55-56). En avgörande skillnad gentemot en konventionell förståelse är inte minst att de som utgör styrningens "objekt", exempelvis eleven, klienten eller medborgaren, inte ses som passiva måltavlor. I stället framhävs att styrningen i sig formar själva "objektet" för styrningen. Begreppet governmentality fångar snarare styrningens rationalitet, hur föreställningar, konventioner och tankesystem är relaterade till politiska interventioner av olika slag (Dean 1999).

Utifrån ett sådant perspektiv kan innebörden av att vara en god medborgare ses som ett resultat av en bred repertoar av styrningstekniker, utspridda över hela det sociala fältet. Enligt Foucault (I99I) utgår styrning inte med självklarhet från statsapparaten, utan styrning utgörs av en bred repertoar av teknologier som opererar i hela samhället.

Maktutövning är produktiv, men samtidigt begränsande. Foucault gör en distinktion mellan "maktteknologier" (technologies of power) och "jag-teknologier" (technologies of the self). Medan maktteknologier "reglerar enskilda människors uppträdande och tar dem i anspråk för särskilda ändamål eller undertrycker dem" (Foucault 2008, s. 263), så handlar jag-teknologier snarare om människors självblivande, skapande av sig själva som subjekt. Dessa tekniker, markerar Foucault,

gör det möjligt för enskilda människor att av egen kraft eller med andras hjälp genomföra ett visst antal ingrepp på sina egna kroppar och själar och tankar, sitt eget uppträdande och sätt att vara - och på så sätt omvandla sig själva i syfte att uppnå ett visst tillstånd av lycka, renhet, vishet, fulländning eller odödlighet. (Foucault 2008, s. 263.)

I den här artikeln tar vi avstamp i den forskningsinriktning som tillämpat begreppet governmentality på frågor om skola, lärande och utbildning (se t.ex. Hultqvist \& Petersson 2000; Fejes \& Nicoll 2008; Fejes \& Dahlstedt 20I2; Popkewitz \& Brennan 1998; Popkewitz 2008). Skolan behandlas här som en av de många domäner där denna ständigt pågående fostran av "goda medborgare" utspelar sig (Popkewitz 2008). 
Skolan är en viktig arena i samhällsbygget, och den kan ses som en knutpunkt för allehanda makttekniker och relationer, som involverar en rad olika aktörer, i såväl som utanför skolan.

Fostran i skolans regi bygger på ett mer eller mindre starkt inslag av normalisering, där vissa förmågor eller karakteristika lyfts fram som goda, önskvärda och eftersträvansvärda, i relation till andra, som framställs som ofullbordade, problematiska och i behov av "omskolning" (Popkewitz \& Brennan 1998). Vad gäller fostran i dagens skola, påpekar Kenneth Hultqvist och Kenneth Petersson (2000, s. 503) att de läroprocesser som äger rum inom skolans domäner:

både förutsätter och önskar iscensätta lärare och andra grupper av medborgare som aktiva, självstyrande och engagerade människor som både vill och förmår genomföra det som förväntas av dem och som de egentligen - innerst inne förväntar sig själva.

Det är med andra ord en alldeles speciell typ av medborgare som skolan tar sig för att fostra, formad enligt och anpassad till det samtida, "avancerat liberala" samhällets villkor och förväntningar. Denna medborgare är flexibel, anpassningsbar och ansvarstagande (Österlind I998; Carlbaum 20I2; Harling 2017). Om skolan tidigare i historien utgjorde en starkt disciplinerande kraft där elever har fostrats till medborgare genom en rad disciplinerande tekniker, så har inslaget av jag-teknologier blivit alltmer framträdande i skolans vardag. Under de senaste decennierna har en stor del av skolans fostransuppdrag kommit att ägnas åt att motivera eleverna, stärka deras självtillit och vilja till att ta egna initiativ (se Hultqvist \& Petersson 2000; Dovemark 2007; Dahlstedt \& Olson 20I3; Terning 2016).

Vi ska här fördjupa oss i ett specifikt sammanhang som tydligt åskådliggör en sådan typ av fostran, nämligen skolan som arena för trygghetsskapande fostran. Vi ska här visa på en bred repertoar av pedagogiska interventioner där sådana jag-teknologier mobiliseras. Utgångspunkten är en delstudie som genomfördes i en storstadskommun mellan december 2015 till mars 20I6. I studien genomfördes sammanlagt 25 intervjuer med olika lokala aktörer involverade i det lokala brottsförebyggande arbetet - såsom demokratiutvecklare, trygghetssamordnare, utvecklings- 
ledare, projektledare, områdesutvecklare, socionomer, skol- och fritidspersonal, rektorer, polis, representanter för allmännytta samt ideella föreningar. I denna artikel är det arbetet med en specifik intervention som gjorts i relation till skolan som står i fokus, där det framför allt är sammanlagt $\mathrm{I} 6$ intervjuer med några av de socionomer, trygghetssamordnare, områdesutvecklare, fritidspersonal, rektorer och polis som samverkar kring denna intervention som analyseras. I vår analys fokuserar vi först och främst hur de intervjuade ser på värdet av och genomförandet av interventionen. För att få inblick i denna intervention följdes även två undervisningstillfällen i två skolor i kommunen ifråga.

\section{Skola, fostran och trygghet}

Hos de lokala aktörerna som låtit sig intervjuas finns en samstämmig idé om att motverkandet av våld och annan slags brottslighet kräver snabba och tidiga insatser (Dahlstedt \& Lozic 20I7). I detta hänseende ses just skolan som en särskilt viktig arena. I skolan är det möjligt att nå alla, eftersom alla under sin uppväxt kommer i kontakt med den. Skolan ägnar sig åt kartläggning och ingående granskning av eleverna, både vad gäller det som händer inom och utanför klassrummets väggar. Skolan gör barnen och deras familjer synliga - och nåbara (Donzelot 1979). Skolan är därmed en viktig arena när det gäller att inhämta kunskap om barn och familj, men även som en kontaktyta till både barn, föräldrar och andra aktörer, inte minst polis och socialtjänst, som via skolan kan kopplas in i det preventiva arbetet (Wahlgren 20I4). Skolan framträder härmed som en central domän för samverkan där lokalsamhällets olika aktörer kan "mobiliseras" och samlas (se Petersson 1997; Dahlstedt \& Hertzberg 20II).

I det följande ska vi fördjupa oss i ett specifikt exempel på hur skolan kan fungera som en nod för lokalt trygghetsskapande arbete som bygger på samverkan mellan olika lokala aktörer. Vi vill i analysen visa på hur trygghetsskapande fostran iscensätts, vilka motiv som finns till denna fostran och vad det är för slags subjekt som fostran är tänkt att resultera i. Analysen tar avstamp i bakgrunden och motiven till denna intervention, i form av iakttagelser om utbrett våld på gator och i skolan. I relation till dessa utmaningar ses skolan som viktig i det lokala trygghetsarbetet. 
Därefter fokuserar vi på hur fostran iscensätts (genom vilka tekniker), först och främst genom reflektion, bekännelser, mentorer och scenarier. Avslutningsvis riktar vi uppmärksamhet mot de tänkta effekterna av fostran, i form av skapandet av särskilda typer av lärande subjekt (med bestämda förmågor och egenskaper).

\section{Motivbilden}

Rektorn på en F-9-skola i kommunen beskriver motivbilden enligt följande: När han tillträdde för ett par år sedan kunde han snart konstatera att det fanns en, som han beskriver det, "väldig hög frekvens av våld" på skolan. Rektorn berättar att han redan under de tre första veckorna på högstadiet gjorde mellan tio och tolv polisanmälningar om misshandel och mellan två och tre orosanmälningar till socialtjänsten - i veckan. Som motiv till insatserna i skolan tjänar inte minst beskrivningen av oengagerade föräldrar (jfr Dahlstedt \& Lozic 20I7). Oroligheterna gällde allt från bråk till grovt våld och kriminalitet. En socialpedagog på samma skola, som lyfter fram föräldrarollen som en avgörande trygghetsfaktor, berättar att oroligheterna inte bara involverade högstadiet utan också mellanstadiet:

Det fanns mycket extremt våld bland eleverna. Vi pratar om årskurs ett och tre ... grovt våld bland de yngre eleverna ... ett jättestort problem [...] Föräldrarna är inte hemma lika mycket bland eleverna nu som de har varit tidigare. Föräldrar som är involverade, det skiljer sig. Vi kallar till ett föräldramöte och det är tre föräldrar som kommer.

Rektorn beskriver självkritiskt en situation där det under många år funnits ett gap mellan skolledning och lärare. ”Dörren var alltid stängd hos rektorn." "Handlingsplaner definierades som ett dekret." Under lång tid bidrog detta till att skapa en otrygg miljö på skolan, för såväl anställda som elever. Situationen var dock inte unik. Liknande erfarenheter och rapporter fanns även från andra skolor i kommunen och dessa rapporter fick kommunen så småningom att ta initiativ till en rad samlade åtgärder i syfte att bryta trenden och främja tryggheten i kommunen.

I fokus för flera av dessa initiativ stod skolan. I en av kommunens åtgärdsplaner för arbetet med trygghet och säkerhet slås fast att skolor, förskolor och fritidshem tillsammans är "en viktig bas för social prevention". 
"Våldet i familjen, våldet på skolgården, mellan eleverna, allt häger ihop med våldet på gatorna", noterar också en socialarbetare som arbetar i den enhet som har ansvar för det förebyggande arbetet i kommunen.

Diskussioner mellan representanter för socialtjänst och rektorer från några skolor i kommunen påbörjades år 2012 och dessa diskussioner kom bland annat att resultera i ett trygghetsskapande projekt som kom att involvera ett antal skolor i kommunen. Beslutet om att dra igång projektet togs av socialnämnden i början av 20I4. Kort därefter följde ett antal representanter med en svensk delegation på studiebesök till USA och Skottland, där den modell för brottspreventivt arbete som projektet baseras på har utarbetats och satts i bruk. Intresset för att hitta konkreta modeller för det trygghetsskapande arbetet, med skolan i fokus, fanns nämligen inte bara i kommunen utan på en rad andra platser runt om i landet. Under 2015 startades projektet upp i kommunen för att därefter utvärderas varje år. Planen är att projektet med utgångspunkt i erfarenheterna av dessa utvärderingar efter tre år ska utvecklas till att involvera alla skolor i kommunen.

Initiativet organiseras av en enhet med ansvar för förebyggande arbete vid socialtjänsten, men bygger på samverkan mellan olika lokala aktörer, däribland socialtjänst, skola, polis och räddningstjänst. Tillsammans bildar dessa aktörer en referensgrupp, som både följer och stödjer arbetet. Varje aktör har sina specifika uppdrag, ansvarsområden, kompetens och ingång till frågan om trygghet och ungdom, men ur de medverkande parternas synvinkel har denna samverkan på det hela taget varit en styrka, i det hänseendet att olika resurser och kompetenser har kunnat sammanföras och tillsammans skapa ett mervärde i det trygghetsskapande arbetet.

\section{Iscensättandet av trygghetsarbetet}

Initiativet baseras på en modell som går ut på att, först, identifiera en uppsättning faktorer som på olika sätt ökar risken för att individer endera använder eller blir utsatta för våld och, därefter, att förebygga dessa risker. Med utgångspunkt i denna modell placeras den enskilda individen in i en strukturerande miljö som består av tre olika nivåer: relationer (familjemedlemmar, vänner och bekanta), närmiljö (skolor, arbetsplats 
och bostadsområde) och samhälle (sociokulturella normer och villkor som genererar konflikter). Det finns alltså en mängd riskfaktorer, som kan identifieras på olika nivåer, som tillsammans påverkar individernas värderings- och handlingsmönster.

Modellen tar specifikt avstamp i en normkritisk ansats, där det är relationerna mellan stereotyper, könsroller och jämställdhet som står i fokus. Utgångspunkten är att rådande könsnormer i sig utgör en risk för konflikter och våldsamma relationer, som till exempel kan ta sig uttryck i våld ute på skolor och på offentliga platser, likväl som i nära och privata relationer. Initiativet syftar närmare bestämt till att öka medvetenheten om verbalt, psykiskt, fysiskt och sexuellt våld bland barn och unga samt bidra till en förändring av rådande sociala normer, med särskilt fokus på stereotypa könsroller. Även om syftet med initiativet i den meningen är att bidra till förändring så är syftet inte, understryker chefen för enheten som ansvarar för kommunens förebyggande arbete, att "förändra" barnet: "Vi ska inte ändra på barnen, utan på oss själva. Vi ska ge barnen möjlighet att bli vad de vill, utan att kategoriseras utifrån våra förväntningar." Siktet är snarare inställt på att, steg för steg, förändra föräldragenerationens förväntningar, däribland både lärare och föräldrar. Vi återkommer till detta längre fram.

En central del av initiativet består i att utbilda mentorer ute på de deltagande skolorna, det vill säga elever som aktivt involveras i det brottspreventiva arbetet. Mentorer rekryteras bland elever som går i årskurs 8, för att de sedan under årskurs 9 själva ska hålla i undervisningspass för elever som går i årskurs 6. Ålder fungerar här som ett selektionskriterium, detta för att säkerställa att mentorerna har nått en viss mognadsnivå. Mentorer väljs ut av lärare på skolan, utifrån bedömd lämplighet för uppdraget. Proceduren kan därmed ses som ett uttryck för en maktteknologi, som består i att skolans auktoriserade bedömningssystem och värdering av lämplighet mäter, rangordnar och utser vilka elever som lever upp till det som anses vara lämpligt och moget nog för att tjäna som förebildligt för övriga elever. De elever som enligt denna procedur väljs ut som lämpliga mentorer genomgår därefter en utbildning som arrangeras av särskilda referensgrupper som bildats ute på skolorna, bestående av personal på skolan samt företrädare för polis och räddningstjänst. För 
det mesta är utbildningen förlagd under ett antal dagar i socialtjänstens lokaler. Programmet löper under ordinarie skolschema och innehåller elva pass. Personalen ser till så att mentorerna följer utbildningen. Under en uppstartsfas håller socialarbetare i passen tillsammans med involverad skolpersonal. Företrädare för polis och räddningstjänst medverkar vid enskilda tillfällen, beroende på vilket tema som passet behandlar.

Efter genomgången utbildning är det dags för mentorerna att själva hålla i undervisningspass för elever i årskurs 6 på skolan. Klasserna delas upp i grupper om ungefär femton elever och varje grupp leds av tre mentorer. De tre mentorerna har olika roller under undervisningspassen. En av mentorerna pratar, en skriver på tavlan och en tredje håller tiden - eftersom varje pass är indelat i olika moment, som beräknas ta en viss tid. Passet inleds med att en av mentorerna redogör för de regler som gäller under passet, exempelvis att det inte är tillåtet att avbryta mentorerna. Därefter följer en kort introduktion av vad passet ska handla om och hur det är upplagt.

Som stöd för undervisningspassen använder mentorerna sig av en särskilt framtagen handbok eller manual, med konkreta förslag till upplägg, innehållande en uppsättning övningar och frågor för respektive pass. Varje pass är 45 minuter och behandlar ett specifikt tema som på olika sätt rör trygghet och otrygghet, på skolan eller på fritiden, i området eller på andra platser. Temat illustreras vanligen av ett inledande filmklipp. Filmklippen kan vara hämtade från Youtube, ibland på svenska och ibland på engelska. Ett annat exempel på filmer som visas är en serie om totalt åtta kortfilmer framtagen av Utbildningsradion, Vara vänner. Filmerna är särskilt anpassade till grundskolan F-3 och finns fritt tillgängliga online. En av filmerna behandlar till exempel temat "mobbning" och gestaltar en situation där ett barn blir mobbat i en ny skola. Filmen avslutas, liksom andra filmer i serien, med ett annat scenario, som visar hur barnen på skolan kunde eller borde ha betett sig för att välkomna den nya eleven. Dessa scenarier tjänar därefter som underlag för en diskussion mellan mentorer och eleverna i klassen, utifrån det tema som filmen berört. Denna diskussion kretsar oftast kring frågor som rör normer och värderingar, förhållningssätt och beteenden, utifrån scenariot, vad kunde eller borde eleverna ha gjort i stället? 
Rektorn på en av skolorna beskriver upplägget enligt följande: ”Till exempel: Du och din kompis bor i en korridor och din kompis puttar in en tjej i väggen. Tjejen går bara vidare. Var gör du, liksom? Skrattar du med? Vad skulle du säga till din kompis? Skulle du prata med tjejen efteråt?" Om eleverna inte kommer på något att säga och är tysta erbjuder manualen en uppsättning färdiga exempel som mentorerna kan välja att ta upp. Passet avslutas med att gruppen planerar ett rollspel som får illustrera dagens tema.

\section{Fostran till trygghet}

Själva poängen med upplägget är att de vuxna ska inta en så undanskymd roll som möjligt i denna del av arbetet och att ansvaret för genomförandet huvudsakligen överlåts till mentorerna och eleverna. Undervisningen består i en mobilisering av en bred repertoar av jag-teknologier, där barnen fås att mobilisera sina egna krafter och viljor. Rationaliteten i det förebyggande arbetet beskrivs enligt följande, av rektorn på en av skolorna: "Barnen ska själva medvetandegöras i hur man beter sig mot varandra. Ska vi göra så här? Vad skulle jag kunna göra för att förändra det?” Det är alltså de unga som får initiativet. Det är de som har möjlighet att skapa trygghet. Förutsättningen för skapandet av trygghet är elevernas aktiva deltagande: "Det är när man är aktiv som man börjar förändra normer."

Utifrån denna tankegång beskrivs eleverna inom interventionen som "förändringsagenter", som aktivt ska verka för förändring inte bara i klassrummet utan även - och desto viktigare - runt om i det omgivande samhället. "De ska vara agenter där ute på skolgården”, säger en lärare som är involverad i programmet. "Om de ser våld eller hör något ska de antingen gå till en lärare de känner sig trygga med eller försöka lösa konflikten själva.” Idén är att eleverna ska känna sig trygga och bidra till att på olika sätt skapa trygghet där de befinner sig genom att inte bara se, utan också respondera mot de eventuella överträdelser som görs runt omkring dem. En rektor beskriver i sådana ordalag initiativet som ett sätt att få barnen att "hjälpa varandra att se hur man kan vara aktiv och stoppa det här bråkiga som inträffar”. Detta gör - sammantaget - barnet till "förändringsagent", "inte bara en passiv åskådare". På så sätt kan man 
säga att skolans trygghetsskapande fostran har en räckvidd som sträcker sig vida utanför skolan och klassrummet. Den "förändrings-agens" som initiativet är tänkt att skapa kan eleverna göra bruk av också på sin fritid. Genom initiativet blir det därmed, säger en polis, möjligt att också nå in i och påverka familjelivet.

Om barnen påverkas i sexan så kommer de hem och kan påverka sin familj [...] Tänk om barnen får reda på diskussionen om att man inte får slå barn och så kommer de hem och kanske ser en annan familj, där någon blir slagen. "Det där är inte okej." Vad det vore häftigt om barnen säger ifrån: "Mamma, jag såg att pappan i den här familjen slog henne. Jag tänker göra en polisanmälan. Jag vill att du hjälper mig med polisanmälan.”

Därmed blir hela familjen föremål för pedagogisk intervention (se Donzelot 1979; Crozier 1998), där både barn och föräldrar blir delaktiga i det trygghetsskapande arbetet (jfr Dahlstedt 2009a, 2009b). Utifrån citatet framstår denna tänkta förändrings-agens inte enbart som uttryck för ett slags jag-teknologi, som på olika sätt manar till barnens egna, inre krafter och viljor att reglera sig själva. Denna tänkta förändrings-agens bygger även på en logik som närmast för tankarna till det som Foucault (2008) benämner maktteknologi, som i olika avseenden bygger på att barnen samtidigt ska fostras till att reglera andra människors beteende och forma sin omgivning genom att identifiera olika överträdelser i sin vardag och bidra till att skapa trygghet.

I intervjuerna beskrivs initiativet som lyckat. I den första kvalitativa utvärdering av initiativet som kommunen genomfört påvisas en viss positiv förändring av ungdomars förhållningssätt till våld och en generellt sett minskad våldsnivå ute på skolorna. I utvärderingen rapporteras bland annat att de elever som deltar i initiativets undervisning upplever sig vara mer trygga och att de rör sig på ett annorlunda sätt i sin omgivning. Från en av skolorna rapporteras vidare att eleverna efter ett års verksamhet upplever mindre våld på skolan. Även i intervjuerna lyfts flera tecken fram som tycks peka på att initiativet haft vissa effekter. En rektor berättar till exempel att antalet orosanmälningar till socialtjänsten har minskat drastiskt, från två till tre gånger per vecka, till två per termin. När det gäller fostran av eleverna genom förändrings-agens lyfter 
en rektor fram följande händelse som ett konkret exempel på hur han menar att initiativet haft en viss positiv effekt:

Det var sent en eftermiddag och några elevmentorer spelar tennis. Det kommer en mamma och hennes fyraåriga son. Hon ska hämta sitt lite äldre barn på vårt fritids och de hör plötsligt hur hon, med ganska stor kraft, smäller till fyraåringen i huvudet, två gånger. Och det första de gör är att gå fram till mamman och säger: "Men, vad gör du för någonting? Man får inte slå barn." Hon svarade typ: "Bry dig inte om det. Strunt i mina ungar." [...] De flesta vuxna hade nöjt sig med det och sagt: "Ja, men det är en dum mamma", och så. Men de gjorde inte det, utan de kom upp till kuratorn och berättade att: "Vi såg det här och det var den här mamman med pojken i den här klassen." De sade: "Vi stannar för att vittna så att det blir en polisanmälan." Så de ställde upp på att vara vittnen till den här misshandeln. Vi kunde också gå in i vårt kamerasystem. Man kunde verkligen se på vilket bra sätt eleverna i nian gick in i den här händelsen.

Exemplet visar på hur den tänkta förändrings-agensen skapas genom jagets och maktens teknologier. Idén är att förändring kommer inifrån, utifrån den enskilde individens motivation och vilja. Förändring kan, enligt argumentationen, inte kommenderas fram. Samtidigt riktas förändringen inte bara inåt den enskilde individen, till en förändring av jaget, utan också utåt, till en förändring av omgivningen. Barnens ögon gör det möjligt att kartlägga omgivningen och identifiera potentiella risker och överträdelser, som därefter kan möjliggöra förändring. I citatet framgår dessutom hur elevernas kartläggande ögon beskrivs i relation till skolans kamerasystem, en annan form av maktteknologi, övervakningens apparatur.

Scenarier som det här används, berättar en lärare, som ett pedagogiskt medel för att mana eleverna till reflektion kring de val som de ställs inför i de olika situationer de möter. Målet med denna reflektion är att eleverna ska lyssna till andras sätt att tänka för att därefter själva komma fram till hur de ska "handla rätt" i konkreta situationer.

Barnen ska börja reflektera över verkliga situationer som åtminstone en elev har varit med om. [...] Barnen får reflektera över vad som händer i en situation och hur de kan göra för att göra rätt. De börjar tänka på det. Annars ... ” Du får inte göra det!" ... "Sluta med det!" ... Här finns ett jättebra tillfälle där barnen får reflektera och lyssna på vad kamraterna tänker och så bygga upp det här med hur man ska handla rätt. 
Reflektion fungerar här som en central lärande praktik, för den enskilde eleven såväl som för gruppen. Tanken är eleverna genom dialog med andra ska lära sig resonera med sig själva och med andra, att formulera sina erfarenheter och synpunkter, att respektera andras synpunkter och att i dialog med andra både revidera och stå för sina egna. Genom denna dialog kan eleven så småningom hitta fram till hur hon "kan göra för att göra rätt". Genom denna process "aktiveras" eleverna samtidigt som deras normer och värderingar görs synliga och i sin tur relateras till rådande normer. På så sätt formas eleverna till aktiva subjekt som styr både sig själva och andra i förhållande till gällande normer (Axelsson \& Qvarsebo 20I4).

I och med att eleverna erbjuds att "aktivera" sig själva, och i och med att eleverna accepterar ett sådant erbjudande genom att delge eller "avslöja" sina inre tankar för de andra, kan vi med hänvisning till Foucault (2008) säga att det är ett slags jag-teknologi som sätts i bruk. Vad som utspelas i denna situation är en form av bekännelse där elever inbjuds att dechiffrera sitt jag, sätta det i förhållande till vad de uppfattar som normalt och genom detta skapa ett nytt och bättre jag.

Bekännelsen fungerar som en jag-teknologi varigenom eleverna reflekterar över sig själva, individuellt och i dialog med andra, som ett medel för att förändra sig i riktning mot definierade ideal. Förmågan att ständigt reflektera över sig själv i förhållande till den omgivande världen, och att dela dessa reflektioner i dialog med andra, är ett av de mest centrala kännetecknen för det lärande subjekt som undervisningen går ut på att fostra.

Av intervjuerna framgår dock att lärarna inte är helt frånvarande i denna läroprocess, även om deras roll är något undanskymd. Lärarnas roll består huvudsakligen i att stödja och underlätta elevernas fria reflektion. En lärare berättar att ett sätt att bidra till att få elever att reflektera över "rätt" och "fel" och lära sig hur man kan tänka och göra annorlunda kan vara att få eleverna att titta tillbaks på händelser som inträffat och fråga dem: "Vad hände?"

Elever som hamnar i problem ... då har jag lärt mig en teknik: "Vad hände?" Och så får eleven berätta om det som hände. Ok! Och hur kunde du ha gjort annorlunda för att ändra situationen, för att undvika att slå eleven? Och då får 
eleven säga till mig vad han skulle ha gjort annorlunda. [...] Okej ... då säger jag till nästa gång om det uppstår en liknande situation: Då vet du vad du ska göra! Eleven blir medveten om att det inte var okej det du gjorde ... men hur kunde du ha gjort annorlunda? [...] Så det är inte något som kommer från mig. Det är något som kommer från eleven själv. Så det var ganska positivt att använda den här tekniken ... att låta elever reflektera över situationen. Det är en bra träning inför framtiden, för när man blir vuxen då kan man inte använda våld.

Genom att läraren i undervisningen ställer sådana enkla frågor kan eleverna lära sig att de alltid har ett val, att de alltid kan göra annorlunda. Eleverna är därmed inte offer för omständigheterna, utan de har alltid ett ansvar. Eleverna skapas på så sätt som ansvarstagande subjekt. Insikten om att eleverna alltid har ett val kommer dock inte från läraren, utan inifrån eleverna själva, genom reflektionens makt. Genom reflektion fås de att både se och acceptera konsekvenserna av sina egna handlingar, att ta ansvar för sig själva och inte skjuta över ansvaret på andra (Löf 20II). Rationaliteten följer i allt väsentligt den som återfinns i andra KBT-inriktade insatser: tanken är att de som insatserna riktas mot ska se sig själva som ansvariga för sina egna liv, för sitt eget väl och ve (Axelsson \& Qvarsebo 2014).

Samtidigt är det inte bara eleverna som formas genom det värderingsarbete som bedrivs i klassrummet, utan även lärarna. De reflektioner som iscensätts får nämligen också lärarna att jobba med sig själva. En av de lärare som berättar att hen genom sitt deltagande i initiativet "har jobbat mycket med mig själv också" beskriver detta arbete med självet i följande termer:

Jag blir mer medveten om hur jag ska jobba säkert, om hur jag tänker om mig själv i relation till andra människor, hur jag ska jobba med barnen, och sen får jag naturligtvis jobba med mig själv. Jag är en person som gör skillnad på killar och tjejer. Då är det något som jag måste jobba med också [...] Att vara medveten om hur man pratar med barnen. Det är ett konstant arbete varje dag. Man påminner sig själv hela tiden. Ibland gör man fel, men man inser att man gör fel genom att erkänna det, man står för vad man gör och försöker att förbättra det.

Läraren beskriver här ett kontinuerligt lärande, som utgör ett belysande exempel på ett slags jag-teknologi. Denna teknologi består i ett "konstant arbete varje dag", där hen gradvis "blir mer medveten", inte minst 
genom att hen "påminner sig själv hela tiden". Ett viktigt inslag i detta lärande är bekännelsen - "man inser att man gör fel genom att erkänna det”. Bekännelsen är i detta fall individuell, riktad inåt jaget, men utgör ändå startpunkten för ett lärande som tar sikte på att bli bättre: "man står för vad man gör och försöker att förbättra det". Liksom eleverna kommer därmed även lärarna att bli mer medvetna och reflekterande, både om sig själva, sina normer och värderingar, och om omgivningen. Lärarna blir, genom användandet av en rad metoder som bygger på reflektion, aktiva subjekt inte bara i formandet av eleverna som trygghetsskapande subjekt, utan även i formandet av sig själva till sådana subjekt (se t.ex. Olsson \& Petersson 2008).

\section{Avslutande diskussion}

Med utgångspunkt i ett analytiskt perspektiv inspirerat av Foucault och hans tankar om styrning har vi i denna artikel undersökt trygghetsskapande fostran i skolan. Fokus har riktats mot en specifik lokal intervention, men i skolor runt om i landet görs - i olika tappningar - en mängd interventioner av liknande slag (Löf 20II; Kvist Lindholm 20I5). Det förebyggande arbete som vi intresserat oss för åskådliggör, menar vi, en rad pågående politiska förändringar.

Utifrån det analytiska perspektiv som anammats i artikeln kan skolan förstås som en domän för etablerande av normer och iscensättande av skilda styrningsmekanismer. Såsom det framstår i det material som analyserats i denna artikel så behöver det skapas trygghet för både elevernas och samhällets bästa. Men för att eleverna ska kunna bidra till trygghetsarbetet behöver de först fostras till att vilja åstadkomma förändring. Vi har i analysen pekat på vad som skulle kunna beskrivas som ett slags vilja att aktivera, en form av styrning som i hög grad manar till individens motivation och vilja att göra aktiva val och aktiva ställningstaganden - i namn av frihet, ansvarstagande och trygghet. Analysen har dock påvisat att det finns ett rätt val och en rätt väg, utstakade med utgångspunkt i rådande normer, som eleverna med olika medel ska fostras till att själva välja. Det fria valet som alla elever står inför framstår därmed inte som något val, utan snarare som ett påbud: alla har alltid ett val och alla måste 
välja. Ansvaret för att göra ett val - och att göra rätt val - är individens eget. Ansvaret för individens liv här och nu såväl som för individens framtid förläggs till individen själv, det vill säga till det enskilda barnet (Löf 20II).

Den form av styrning som interventionen möjliggör består av en rad olika jag-teknologier. I analysen har vi framför allt lyft fram en sådan teknologi, bekännelse. Bekännelse i form av reflektion är ett centralt inslag i det trygghetsskapande arbete som bedrivs ute på skolorna. Bekännelsen är dock inte något som tvingas på eleverna. I stället inbjuds elever till att aktivt delta i det fortlöpande reflektionsarbetet på grundval av sin egen frihet. Genom att reflektera kring sitt eget och andras handlande förändrar eleverna sitt eget beteende samtidigt som de påverkar andras beteende. Genom att reglera sig själva och förändra sina jag till vad som bedöms som önskvärt reproducerar de normer för gott uppförande och därmed deltar de även i regleringen av andras uppförande. På så sätt är jag-teknologin, regleringen av jaget, också kopplat till maktteknologin, regleringen av andra. Ett av de medel genom vilka bekännelsen möjliggörs är scenariot - som manar den enskilde eleven att ta ställning, det vill säga att göra val, och att reflektera över dessa val (jfr Wahlgren 20I4).

Mentorskapet är en annan viktig del av arbetet. Mentorskapet kan närmast beskrivas som ett slags förebildande rationalitet, som bygger på en reglering av jaget och av andra. Mentorerna fungerar som förebilder, vars goda exempel de andra eleverna kan följa, i sitt eget tänkande och görande. Mentorn får därmed en central pedagogisk funktion genom att så att säga staka ut vägen till det goda och önskvärda, det som de andra eleverna behöver anamma och förkroppsliga (jfr Fejes \& Dahlstedt 20I7). Mentorerna bidrar därmed till att reglera både sig själva och andra elever. Mentorerna görs möjliga utifrån skolans ordnings- och bedömningssystem. För att de ska kunna fungera som förebilder behöver de nämligen först väljas ut av lärarna, för att de i olika avseenden ses som just förebildliga. Därefter behöver de formas till förebilder, det vill säga fås att välja den - som det ses - rätta vägen. Mentorerna beskrivs av de intervjuade som särskilt viktiga i det förebyggande arbetet, just på grund av sin ålder. Eftersom de är unga anses de ha lättare att nå fram till de unga än de vuxna har. Därmed blir ungdomarna nåbara och samtidigt styrbara. 
Utifrån den modell som initiativet utgår från identifieras en uppsättning faktorer som ökar risken för våld: relationer (familjemedlemmar, vänner och bekanta), närmiljö (skolor, arbetsplats och bostadsområde) och samhälle (sociokulturella normer och villkor som genererar konflikter). I fokus för den fostran till trygghet som iscensätts i initiativet står de nära relationerna, framför allt i den närmiljö som skolan utgör. Med utgångspunkt i konkreta exempel hämtade från denna specifika miljö manas eleverna till reflektion som - på sikt - kan utrusta dem med en förändrings-agens som kan få dem att utmana relationer och sociokulturella normer i de sammanhang där de rör sig - på skolan likväl som utanför. Därmed kan den fostran som möjliggörs i och genom skolan komma att få effekter vida utanför klassrummets avgränsade kontext. I den meningen skulle man kunna säga att - i princip - hela samhället görs nåbart för pedagogisk intervention och att samhället, i den meningen, blir en skola för ständigt pågående fostran till trygghet (jfr Hultqvist \& Petersson 2000). Den förändrings-agens som initiativet är tänkt att frammana kan därmed ses som en form av styrning som bygger på jagets och maktens teknologier, där reglering av jaget är intimt förbundet med reglering av andra.

Samtidigt tycks den uppsättning av riskfaktorer som finns utanför skolans specifika kontext - förlagda till det omgivande samhället, dess strukturer och sociala villkor - falla utanför skolans trygghetsskapande fostransarbete. Arbetet är inriktat mot elevernas inre, med siktet inställt på att förändra deras uppförande och skapa en beredskap och vilja att själva åstadkomma förändring. Detta inåtriktade arbete är dock inte kopplat till ett bredare samhällsarbete som riktas utåt, med siktet inställt på att förändra de ojämlika sociala villkor som kan skapa spänningar och konflikter. Det är snarare eleverna själva som görs till förändringens agenter, med ansvar för att själva skapa förändring och trygghet. I denna process ställs kommunerna inför stora utmaningar när det gäller att samordna olika åtgärder.

Den specifika intervention som vi har ägnat oss åt att analysera är i någon mening symtomatisk. Den åskådliggör ett bredare skifte i styrningens rationalitet som ägt rum under de senaste decennierna, i Sverige såväl som i en rad andra länder runt om i världen. I linje med detta skifte 
förläggs allt starkare fokus till individen, som både bärare av problem och av lösningen på dessa. Förändringen kan skönjas inom skolan, men också inom andra delar av välfärdssektorn. Förändringsbenägenhet och anpassningsförmåga är del av ett samtida medborgarideal, som förmedlas i skolan och i samhället i allmänhet. För att nå framgång i dagens samhälle uppmanas individen att ständigt "göra om sig", att anpassa sig till rådande ideal, förväntningar och krav, och stärka sin konkurrenskraft. Det är också i allt väsentligt en sådan ansats som ligger till grund för det trygghetsskapande arbete som bedrivs i det initiativ som vi har undersökt här.

\section{Referenser}

Andersson, Kjerstin (2008) Talking violence, constructing identity. Institutionen för tema, Linköpings universitet.

Andersson, Robert (2004) "Behandlingstankens återkomst", Nordisk Tidsskrift for Kriminalvidenskab, 91, s. 384-403.

Andersson, Robert \& Nilsson, Roddy (2009) Svensk kriminalpolitik, Malmö: Liber.

Axelsson, Thom \& Qvarsebo, Jonas (20I4) "Värdegrund och livskunskap som styrningsteknologier", i Axelsson, Thom, Balldin, Jutta \& Qvarsebo, Jonas (red.) Styrningskonst på utbildningsarenan. Upphöjda begrepp i svensk utbildningsdiskurs. Lund: Studentlitteratur.

Bartholdsson, Åsa (2007). Med facit i hand. Normalitet, elevskap och vänlig maktutövning $i$ två svenska skolor. Socialantropologiska institutionen, Stockholms universitet.

Carlbaum, Sara (2012) Blir du anställningsbar lillela vän? Diskursiva konstruktioner av framtida medborgare i gymnasiereformer 197I-20II. Statsvetenskapliga institutionen, Umeå universitet.

Crozier, Gill (1998) "Parents and schools: partnership or surveillance?", Journal of Education Policy, I3, I, s. I25-136. DOI: https://doi.org/I0.1080/0268093980130108

Cruikshank, Barbara (1999) The will to empower. Democratic citizens and other subjects. Ithaca: Cornell University Press.

Dahlstedt, Magnus (2009a) Aktiveringens politik. Demokrati och medborgarskap för ett nytt millenium. Malmö: Liber.

Dahlstedt, Magnus (2009b) "Parental governmentality: involving 'immigrant parents' in Swedish schools", British Journal of Sociology of Education, 30, 2, s. 193-205. DOI: https://doi.org/I0.I080/0I425690802700289

Dahlstedt, Magnus \& Hertzberg, Fredrik (2OII) "Den entreprenörskapande skolan: Styrning, subjektskapande och entreprenörskapspedagogik", Pedagogisk Forskning $i$ Sverige, 16, 3, s. 179-198. 
Dahlstedt, Magnus \& Lozic, Vanja (2017) "Problematizing parents: Representations of multi-ethnic areas, youth and urban unrest", i Ålund, Aleksandra, Schierup, CarlUlrik \& Neergaard, Anders (red.) Reimagineering the nation. Essays on twenty-firstcentury Sweden. Frankfurt am Main: Peter Lang.

Dahlstedt, Magnus \& Olson, Maria (2013) Utbildning, demokrati, medborgarskap. Malmö: Gleerups.

Dean, Mitchell (1999) Governmentality. Power and rule in modern society. London: Sage.

Donzelot, Jacques (1979) The policing of families. London: John Hopkins.

Dovemark, Marianne (2007) Ansvar - hur lätt är det? Om ansvar, flexibilitet och valfrihet $i$ en föränderlig skola. Lund: Studentlitteratur.

Fejes, Andreas \& Dahlstedt, Magnus (2012) The confessing society. London: Routledge.

Fejes, Andreas \& Dahlstedt, Magnus (20I7) "Becoming the role model: youth recreation leaders, occupational choice and a will to include", Discourse: Studies in the Cultural Politics of Education, 3I mars 2017. DoI: https://doi.org/Io.1080/0I596306.2017.1308917

Fejes, Andreas \& Nicoll, Katherine (red.) (2008) Foucault and lifelong learning. Governing the subject. London: Routledge.

Feindler, Eva L. \& Weisner, Scott (2006) "Youth anger management treatments with school violence prevention", i Jimerson, Shane R. \& Furlong, Michael J. (red.) Handbook of school violence and school safety. From research to practice. Mahwah: Lawrence Erlbaum Associates.

Foucault, Michel (1980) Power/knowledge. Selected interviews and other writings 19721977. New York: Pantheon.

Foucault, Michel (I99I) "On governmentality", i Burchell, Graham m.fl. (red.) The Foucault effect. Studies in governmentality. With two lectures by and an interview with Michel Foucault. Brighton: Harvester.

Foucault, Michel (2008) "Självteknologier", i Foucault, Michel, Diskursernas kamp, Stehag: Symposion.

Furedi, Frank (2004) Therapy culture. Cultivating vulnerability in an uncertain age. London: Routledge.

Gundersen, Knut \& Svartdal, Frode (2006) "Aggression replacement training in Norway: Outcome evaluation of II Norwegian student projects", Scandinavian Journal of Educational Research, 50, I, s. 63-8I.

Dor: https://doi.org/10.1080/00313830500372059

Harling, Martin (20I7) Välja vara. En studie om gymnasieval, mässor och kampen om framtiden. Institutionen för samhälls- och välfärdsstudier, Linköpings universitet.

Hultqvist, Kenneth \& Petersson, Kenneth (2000) "Iscensättningen av samhället som skola”, i Bjerg, Jens (red.) Pedagogik. En grundbok. Malmö: Liber.

Hörnqvist, Magnus (2010) Risk, power and the state. After Foucault. London: Routledge.

Irisdotter Aldenmyr, Sara (red.) (20I4) Hyfs, hälsa och gemensamma värden. Studier av skolans komplexa värdegrunds- och fostransuppdrag. Malmö: Gleerups.

Johansson, Thomas (2006) Makeovermani. Om Dr Phil, plastikkirurgi och illusionen om det perfekta jaget. Stockholm: Natur och Kultur. 
Kihlberg, Jakob (2006) "Liberalismen är en naturalism", Fronesis nr 22-23, s. 54-60.

Kvist Lindholm, Sofia (2015) The paradoxes of socio-emotional programmes in school. Young people's perspectives and public health discourses. Institutionen för Tema, Linköpings universitet.

Listerborn Carina (2002) Trygg stad. Diskurser om kvinnors rädsla i forskning, policyutveckling och lokal praktik. Chalmers tekniska högskola, Göteborg.

Löf, Camilla (20II) Med livet på schemat. Om skolämnet livskunskap och den riskfyllda barndomen. Lärarutbildningen, Malmö högskola.

Mulinari, Leandro Schclarek (2015) "Ni är inte välkomna i vårt fina Malmö”, Sociologisk Forskning, 52, 4, 32I-340.

Olsson, Ulf \& Petersson, Kenneth (2008) "The operation of knowledge and construction of the lifelong learning subject", i Fejes, Andreas \& Nicoll, Katherine (red.) Foucault and lifelong learning. Governing the subject. London: Routledge.

O'Malley, Pat (2012) Risk, uncertainty and government. Hoboken: Taylor and Francis.

Petersson, Kenneth (1997) "Mobilisering av gemenskapen", i Arnstberg, Karl-Olov \& Ramberg, Ingrid (red.) I stadens utkant. Perspektiv på förorter. Botkyrka: Mångkulturellt centrum.

Petersson, Kenneth (2003) Fängelset och den liberala fantasin. En studie om rekonstruktionen av det moraliska subjektet inom svensk kriminalvård, Norrköping: Kriminalvårdsstyrelsen.

Popkewitz, Thomas S. (2008) Cosmopolitanism and the age of school reform. Science, education, and making society by making the child. New York: Routledge.

Popkewitz, Thomas S. \& Brennan, Marie (1998) "Restructuring of social and political theory in education", i Popkewitz, Thomas S. \& Brennan, Marie (red.) Foucault's challenge. Discourse, knowledge, and power in education. New York: Teachers College Press.

Popkewitz, Thomas S., Olsson, Ulf \& Petersson, Kenneth (2006) "The learning society, the unfinished cosmopolitan, and governing education, public health and crime prevention at the beginning of the twenty-first century", Educational Philosophy and Theory, 38, 4, s. 43I-449. DOI: https://doi.org/IO.IIII/j.I469-58I2.2006.00203.x

Riele, Kitty te (2006) "Youth 'at risk': further marginalizing the marginalized?", Journal of Education Policy, 2I, 2, s. I29-I45. DOI: https://doi.org/10.1080/02680930500499968

Rose, Nikolas S. (1999) Powers of freedom. Reframing political thought. Cambridge: Cambridge University Press.

Sahlin, Ingrid (2000) Brottsprevention som begrepp och sambällsfenomen. Lund: Arkiv.

Skolverket (20II) Utvärdering av metoder mot mobbning. Stockholm: Skolverket.

Terning, Maria (2016) Myter om gymnasieeleven. En diskursteoretisk studie av dominerande subjektspositioner i politiska texter 1990-2009. Institutionen för pedagogik och didaktik, Stockholms universitet.

Wahlgren, Paula (20I4) De laglydiga. Om skolans brottsförebyggande fostran. Kriminologiska institutionen, Stockholms universitet. 
Wishart, Diane, Taylor, Alison \& Schultz, Lynette (2006) "The construction and production of youth 'at risk', Journal of Education Policy, 2I, 3, s. 29I-304. DoI: https://doi.org/I0.I080/02680930600600390

Österlind, Eva (1998) Disciplinering via frihet. Elevers planering av sitt eget arbete. Pedagogiska institutionen, Uppsala universitet. 


\section{Björn Lundberg}

Naturliga

\section{medborgare}

Friluftsliv och Vad behöver barn och ungdomar lära medborgarfostran sig för att kunna bli goda medborgare? i scoutrörelsen och I Naturliga medborgare undersöker Unga Örnar historikern Björn Lundberg hur scout-

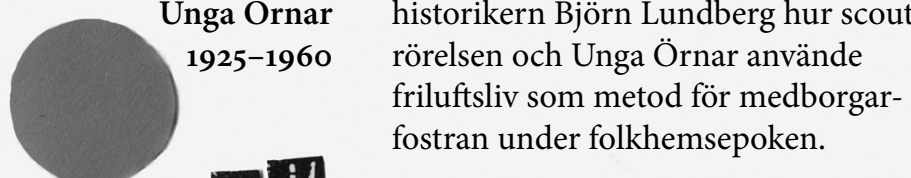

Arkiv förlag, 370 sidor

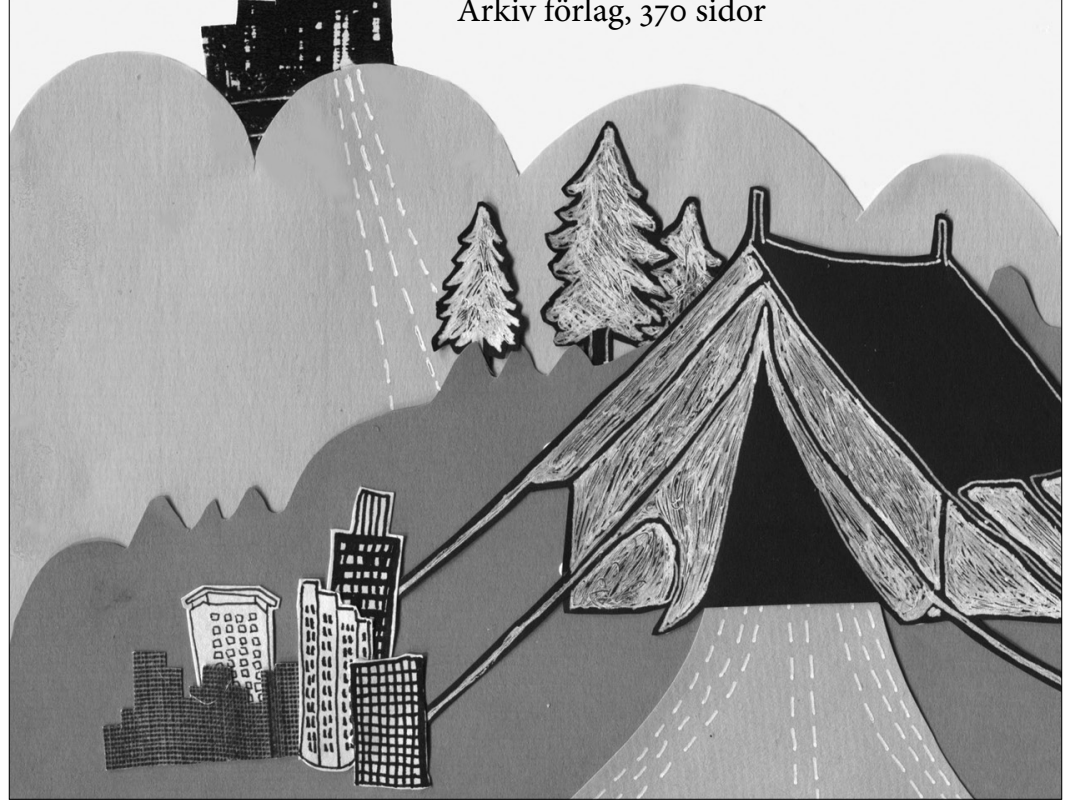

»Läs mer om boken på www.arkiv.nu« 